\begin{abstract}
Гідроксид нікелю иироко використовуеться як активна речовина суперконденсаторів. Найбільи активними є зразки $\mathrm{Ni}(\mathrm{OH})_{2}(\alpha+\beta)$ шарової структури, синтезовані в щілинному діафрагмовому електролізері (ЩДЕ). Вивчено вплив карбонат-аніона на структуру та електрохімічні властивості гідроксиду нікелю, иляхом синтезу зразків в шілинному діафрагмовому електролізері з використанням для розділення електродних просторів діафрагми та катіонообмінної мембрани. Експериментально показано, що при використанні діафрагми в щілинному діафрагмовому електролізері формується фільтрачійний потік із анодного простору (який містить луг з домішкою карбонату) в катодний. Таким чином, зразки, синтезовані з діафрагмою, утворюються в присутності карбонатів, а зразки, синтезовані з катіонообмінною мембраною відсутності карбонатів. Кристалічна структура зразків вивчена методом рентгенофазового аналізу, електрохімічні характеристики - методами ииклічної вольтамперометрії та гальваностатичного зарядно-розрядного циклування в акумуляторному режимі. Проведено порівняльний аналіз характеристик зразків, синтезованих в присутності та у відсутності карбонату. Методом ренгенофазового аналізу та циклічної вольтамперометрії доведена ключова роль карбонат-аніону у формуванні монофазної иарової $(\alpha+\beta)$ модифікації. У відсутності карбонату знижується кристалічність зразків, зменшується вміст а-модифікачї, при високих густинах струму (12 и

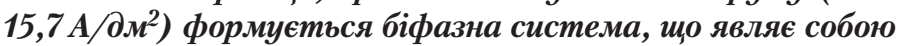
суміш $\beta$-модифікацї та $(\alpha+\beta)$-структури. Вивчення електрохімічних характеристик показало зниження питомої ємності на 14,7-31,4\% для зразків гідроксиду нікелю, сформованого у відсутності карбонатів. Максимальна отримана питома ємність зразків, синтезованих в шілинному діафрагмовому електролізері при густині струму $10 \mathrm{~A} / \partial_{\mathrm{M}^{2}}$ з діафрагмою (в присутності карбонатів) та з мембраною (у відсутності карбонатів) склали 216,8 и 185 мА·год/г відповідно. Для збільшення питомої ємності рекомендовано проводити синтез в щілинному діафрагмовому електролізері при використанні діафрагми, а також вводити додаткову кількість карбонату натрію в аноліт

Ключові слова: гідроксид нікелю, шарова $(\alpha+\beta)$ структура, питома ємність, лужний акумулятор, щілинний діафрагмовий електролізер, карбонат
\end{abstract}

UDC 54.057:544.653:621.13:661.13

DOI: $10.15587 / 1729-4061.2019 .155738$

\title{
INFLUENCE OF THE CARBONATE ION ON CHARACTERISTICS OF ELECTROCHEMICALLY SYNTHESIZED LAYERED $(\alpha+\beta)$ NICKEL HYDROXIDE
}

\author{
V. Kotok \\ $\mathrm{PhD}$, Associate Professor \\ Department of Processes, Apparatus \\ and General Chemical Technology* \\ E-mail: valeriykotok@gmail.com \\ $\mathrm{PhD}$, Senior Researcher \\ Competence center

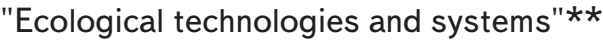 \\ V. Kovale n ko \\ $\mathrm{PhD}$, Associate Professor \\ Department of Analytical Chemistry \\ and Chemical \\ Technologies of Food Additives \\ and Cosmetics* \\ E-mail: vadimchem@gmail.com \\ $\mathrm{PhD}$, Senior Researcher \\ Competence center \\ "Ecological technologies and systems" $* \star$ \\ *Ukrainian State University of \\ Chemical Technology \\ Gagarina ave, 8, Dnipro, Ukraine, 49005 \\ **Vyatka State University \\ Moskovskaya str., 36, Kirov, \\ Russian Federation, 610000
}

\section{Introduction}

Various modifications of nickel hydroxide possess high electrochemical activity [1], which results in their wide application in various electrochemical devices.

$\mathrm{Ni}(\mathrm{OH})_{2}$ and nickel-based double and ternary hydroxides are the main component for the active material of nickel oxide electrode in alkaline $\mathrm{Ni}-\mathrm{Cd}, \mathrm{Ni}-\mathrm{Fe}$ and $\mathrm{Ni}-\mathrm{MeH}$ accumulators [2, 3]. Additionally, nickel hydroxide is also used as a cathode material in lithium batteries [4].

Nickel hydroxide is used as active material for Faradic electrode in asymmetric supercapacitors. $\mathrm{Ni}(\mathrm{OH})_{2}$ is used individually [5] (nanosized [6] or ultradispersed [7]), and as a composite with nanocarbon materials (graphene oxide [8], carbon nanotubes [9]). For thin-layer supercapacitors, a film of nickel hydroxide can be formed on a conductive substrate [10].

Because thin film of $\mathrm{Ni}(\mathrm{OH})_{2}$ is practically transparent and $\mathrm{NiOOH}$ has dark-brown color, nickel hydroxide is used as electrochromic material [11,12].

Nickel hydroxide possesses high electrocatalytic activity and is used for oxidation of various organic compounds [13, 14], and in sensors $[15,16]$.

Each use case requires a specific set of nickel hydroxide parameters. Directed synthesis of products with desired characteristics is the most relevant trend in the modern chemical industry. Determining the influence of synthesis parameters on the properties of resulting hydroxide is a relevant problem. 


\section{Literature review and problem statement}

Synthesis method and parameters determine characteristics of nickel hydroxide, namely irregularity of crystal lattice [17], microstructure [18], crystallinity [19, 20]. In turn, these parameters affect electrochemical activity.

Synthesis method primarily is determined by the type of $\mathrm{Ni}(\mathrm{OH})_{2}$ [21]. Two polymorphs of nickel hydroxides are known: $\beta$-hydroxide (chemical formula $\mathrm{Ni}(\mathrm{OH})_{2}$, brucite-like structure) and $\alpha$-hydroxide (chemical formula $3 \mathrm{Ni}(\mathrm{OH})_{2} \cdot 2 \mathrm{H}_{2} \mathrm{O}$, hydrotalcite-like structure). However, the paper [22] describes the formation of nickel hydroxide structure that is in-between $\alpha-\mathrm{Ni}(\mathrm{OH})_{2}$ and $\beta-\mathrm{Ni}(\mathrm{OH})_{2}$.

$\alpha-\mathrm{Ni}(\mathrm{OH})_{2}$ has higher electrochemical activity than $\beta$-Ni(OH $)_{2}$. However, it has low stability, especially in concentrated alkali and at elevated temperatures. Under these conditions, the metastable $\alpha$-form transforms into $\beta$-form with low activity [23]. In turn, this results in lower capacity. To stabilize $\alpha$-form, stabilizing additives are introduced to nickel hydroxide [24, 25], forming layered double hydroxides (LDH) $[26,27]$. LDH consist of the host crystal lattice, in which part of host hydroxide cations $\left(\mathrm{Ni}^{2}\right)$ are substituted by guest cations such as $\mathrm{Al}^{3+}[28]$ or $\mathrm{V}^{4+}[29]$. The excess of positive charge is compensated by intercalation of various anions [30]. Anions can be those of precursor metal salts (nitrate [31]) or those formed during synthesis (cyanate [32]), or intestinally introduced (carbonates [33, 34]). $\alpha-\mathrm{Ni}(\mathrm{OH})_{2}$, and nickel-based LDH can be prepared using chemical precipitation [34], homogeneous precipitation [35], electrolysis in the slit-diaphragm electrolyzer [36].

$\beta-\mathrm{Ni}(\mathrm{OH})_{2}$ has significantly higher stability during storage and cycling. As a result, this form is widely used in alkaline batteries [37] and hybrid supercapacitors [38]. $\beta-\mathrm{Ni}(\mathrm{OH})_{2}$ can be precipitated chemically at low supersaturation, electrochemically in the slit-diaphragm electrolyzer [39]. High-temperature synthesis [40] and ammine complex decomposition [37] are also used.

Mixed $(\alpha / \beta) \mathrm{Ni}(\mathrm{OH})_{2}$ structure combines advantages of both nickel hydroxide forms [41, 42]. The paper [43] describes the synthesis of highly active nickel hydroxide with layered $(\alpha+\beta)$ structure. Hydroxide was synthesized in the slit-diaphragm electrolyzer (SDE). The sample has demonstrated a high electrochemical activity that exceeds that of $\beta-\mathrm{Ni}(\mathrm{OH})_{2}$ and $\alpha-\mathrm{Ni}(\mathrm{OH})_{2}$. Electrochemical characteristics of $(\alpha+\beta) \mathrm{Ni}(\mathrm{OH})_{2}$ are also improved because of higher oxygen polarization during charge [44] and insignificant aging [45]. High activity of such layered $(\alpha+\beta)$ nickel hydroxide makes electrochemical SDE synthesis promising for industrial implementation.

It should be noted, that nickel hydroxide synthesized in the SDE has a matrix structure that is similar to organic [46] and inorganic [47] composite materials. As described in the paper [39], the matrix is formed by nickel hydroxide with the mother liquor being the filler. When particles pass along the SDE slit, their aging is induced by the field of Joule heat; that has resulted from electric current passing between anode and cathode. Such a combination of growth with partial crystallization results in the formation of a unique $(\alpha+\beta)$ layered structure. Formation and stabilization of such structure are heavy influenced by anions. The influence of anions on the properties of LDH is studied rather well [30]. Namely, the paper [32] describes the positive influence of nitrate ion on the electrochemical properties of $\mathrm{Ni}-\mathrm{Al} \mathrm{LDH}$. While in the paper [33] it is noted that carbonate ions possess greater stabilizing properties. All these studies were conducted for LDH, crystal lattice of which requires the presence of intercalated ions in order to compensate for the excess of positive charge. At the same time, the crystal lattice of promising $(\alpha+\beta) \mathrm{Ni}(\mathrm{OH})_{2}$ has no excess of positive charge, making the presence of anions unnecessary. It is possible, that this is why the influence of anions other than hydroxyl is almost not studied. However, intercalation of additional anions can occur due to their inclusion into the primal particle. Upon crystallization, the included anions can stabilize metastable $\alpha$-phase. At the same time, different anions can impose different degrees of stabilization on $\alpha$-phase. Influence of different anions on the formation and characteristics of $(\alpha+\beta) \mathrm{Ni}(\mathrm{OH})_{2}$ has not been studied. At the same time, the presence of data on the influence of anions will allow improving the characteristics of the layered $(\alpha+\beta) \mathrm{Ni}(\mathrm{OH})_{2}$ structure.

The feature of $(\alpha+\beta) \mathrm{Ni}(\mathrm{OH})_{2}$ synthesis in the SDE lies in that the cathodic chamber is fed with a nickel sulfate solution with the precipitant (hydroxyl-ions) formed due to electrolysis. Thus, only sulfate ions are present in the cathodic chamber. However, the anodic chamber of the SDE is fed with $\mathrm{NaOH}$, which can contain up to $5 \% \mathrm{Na}_{2} \mathrm{CO}_{3}$ if not specifically treated. Because the diaphragm is used, the pressure difference between the anodic and cathodic chamber can lead to the transfer of carbonate ions from the anolyte to the catholyte as a result of diffusion and filtration. It can be concluded that both sulfate and carbonate can play a role in the formation of $(\alpha+\beta)$ layered $\mathrm{Ni}(\mathrm{OH})_{2}$ structure. The influence of carbonate ion on the formation and characteristics of $(\alpha+\beta) \mathrm{Ni}(\mathrm{OH})_{2}$ can be evaluated if its transfer from the anolyte to the catholyte is prevented. In this case, it is most convenient to employ a cation-exchange membrane in Na-form for the separation of SDE chambers.

\section{The aim and objectives of the study}

The aim of the work is to study the influence of carbonate cation on the formation and properties of nickel hydroxide synthesized in the slit-diaphragm electrolyzer with the diaphragm and with the cation-exchange membrane.

To achieve the set aim, the following objectives were set:

- to prepare nickel hydroxide samples in the slit diaphragm electrolyzer with the diaphragm and with the cation-exchange membrane under different current densities;

- to conduct the comparative analysis of structural properties with evaluation of carbonate ion influence;

- to conduct the comparative analysis of electrochemical characteristics of the samples in order to evaluate the role of carbonate ion.

\section{Materials and methods for the preparation and analysis of nickel hydroxide samples}

\section{1. Synthesis of nickel hydroxide samples}

Analytical grade reagents were used in the study, with the exception of $\mathrm{NaOH}$.

Synthesis method $[36,39]$ is based on electrolysis in the flowthrough slit-diaphragm electrolyzer (SDE). The cathodic chamber was fed with nickel sulfate solution (concentration $\mathrm{Ni}^{2+} 12.7 \mathrm{~g} / \mathrm{L}$ ), anodic chamber $-\mathrm{NaOH}$ solution (concentration $50 \mathrm{~g} / \mathrm{L}$ ), at a feed rate of $0.2 \mathrm{~L} / \mathrm{h}$, using the peristaltic pump. Cathode - titanium, to prevent precipitation of hydroxide onto the electrode surface, anode - insoluble nickel. The synthesis was conducted at current densities of 8,10,12 and 
$15.7 \mathrm{~A} / \mathrm{dm}^{2}[36,39]$. For studying the influence of carbonate ion, the anolyte was prepared from partially carbonized alkali ( 5 year storage period). Carbonate content was determined by titration with $0.1 \mathrm{~N} \mathrm{HCl}$ solution in the presence of phenolphthalein and methyl orange.

Current flow through the cathode results in hydrogen evolution and formation of hydroxyl ions, which reacted with nickel cations forming a nickel hydroxide. Formed hydroxide particles flow across the cathode in the electrolyzer slit and are subjected to Joule heat. The precipitate is removed from the electrolyzer along with the catholyte flow. Hydroxide was immediately vacuum filtered and dried at $90{ }^{\circ} \mathrm{C}$ overnight. It was then ground, sifted through $71 \mu \mathrm{m}$ mesh, washed from soluble salts and dried again.

Two series of nickel hydroxide samples were prepared for comparative study (Table 1). The first series of samples was prepared with low-permeability diaphragm Dioramic, separating the cathodic and anodic chambers. The second series was prepared with cation-exchange membrane Nafion in Na-form as the separator.

Nickel hydroxide sample labeling

\begin{tabular}{|c|c|c|}
\hline \multirow{2}{*}{ Current density, A/dm } & \multicolumn{2}{|c|}{ SDE separator } \\
\cline { 2 - 3 } & Diaphragm & Membrane \\
\hline 8 & S0.2-8 & S0.2-8M \\
\hline 10 & S $0.2-10$ & S $0.2-10 \mathrm{M}$ \\
\hline 12 & S $0.2-12$ & S $0.2-12 \mathrm{M}$ \\
\hline 15.7 & S0.2-15.7 & S $0.2-15.7 \mathrm{M}$ \\
\hline
\end{tabular}

\section{2. Study on characteristics of nickel hydroxide} samples

Crystal structure of the samples was studied by means of X-ray diffraction analysis (XRD) using the DRON-3 diffractometer (Russia) (Co-K $\alpha$ radiation, scan range $10-90^{\circ} 2 \theta$, scan rate $\left.0.1^{\circ} / \mathrm{s}\right)$.

Electrochemical properties of nickel hydroxide were studied by means of:

a) cyclic voltammetry in a special YSE-2 cell using the digital potentiostat Ellins P-8 (Russia). The working electrode was prepared by pasting a mixture of nickel hydroxide
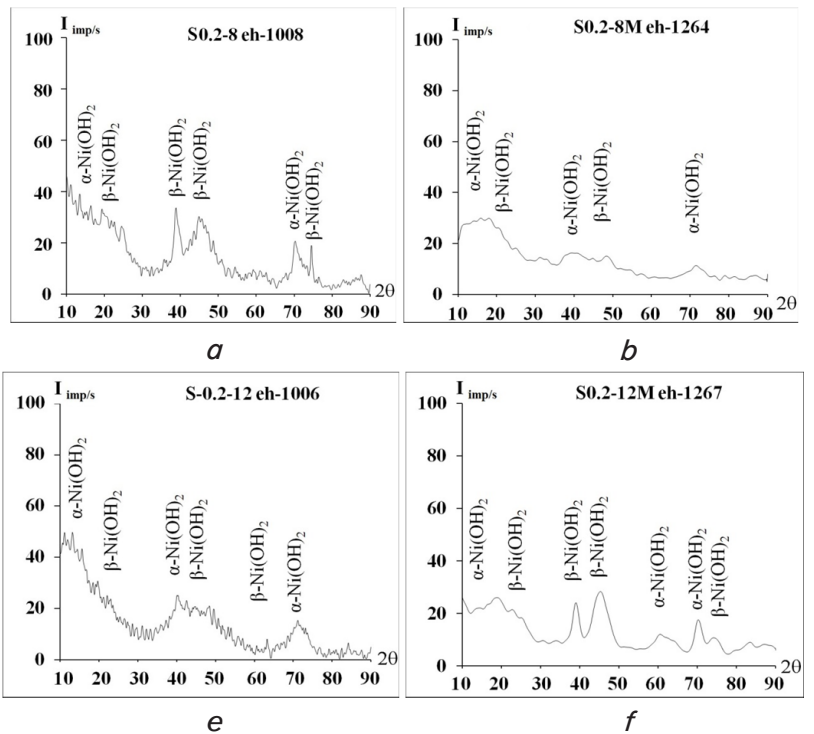

Fig. 1. XRD patterns of nickel hydroxide samples: $a-\mathrm{S} 0.2-8, b-\mathrm{S} 0.2-8 \mathrm{M} ; c-\mathrm{S} 0.2-10 ; d-\mathrm{S} 0.2-10 \mathrm{M} ; e-\mathrm{S} 0.2-12$
Table 1

(81\% wt.), graphite (16\% wt.) and polytetrafluoroethylene (PTFE) (3\% wt.) [50] onto the nickel foam current collector [49]. Electrolyte - 6M KOH. Counter-electrode - nickel mesh, reference electrode $-\mathrm{Ag} / \mathrm{AgCl}(\mathrm{KCl}$ sat.). The electrode was cycled between $200-700 \mathrm{mV}$ (vs $\mathrm{Ag} / \mathrm{AgCl}(\mathrm{KCl}$ sat.)) at a scan rate of $1 \mathrm{mV} / \mathrm{s}$;

b) galvanostatic charge-discharge cycling in the accumulator mode. The study was conducted using a custom-made accumulator model. The working electrode was made by pasting a mixture of nickel hydroxide ( $81 \%$ wt.), graphite (16\% wt.) and PTFE (3\% wt.) [50] on a special current collector (Ni mesh welded onto Ni foil). Electrolyte $-6 \mathrm{M} \mathrm{KOH}$. Counter-electrode - cadmium $(\mathrm{CdO}+$ graphite+oil, pasted onto a special current collector). Cadmium electrode was specifically charged after preparation. The capacity of the counter-electrode was 2 times higher than that of the working electrode, thus the capacity of the accumulator model is determined by the capacity of the nickel-oxide electrode. Reference electrode - Ag/AgCl ( $\mathrm{KCl}$ sat.). Charge - 18 hours with $20 \%$ overcharge (accumulator was charged by $120 \%$ of the theoretical capacity of nickel hydroxide mass on the electrode, accounting for oxygen evolution). The discharge was conducted at the $0.2 \mathrm{C}$ rate (discharge current was 0.2 of the theoretic capacity of the working electrode) to $0 \mathrm{~V}$. Charge and discharge were conducted on the custom-built stand, current density and potential were measured using the digital multimeter UT-70 (China). Specific capacity was calculated based the set current, discharge time and mass of hydroxide on the electrode.

\section{Results of the study on the influence of carbonate ions on characteristics of nickel hydroxide samples}

\section{1. Influence of carbonate ions on sample structure}

Results of XRD analysis have revealed that the samples synthesized with the diaphragm (Fig. 1, $a, c, e, g)$ are $(\alpha+\beta)$ $\mathrm{Ni}(\mathrm{OH})_{2}$ with medium crystallinity, which is in agreement with the literature [43]. Higher curren densities result in higher crystallinity. Similar dependency is observed for the samples synthesized with the membrane (i. e. without carbonate ions) (Fig. $1, b, d, f, h$ ). However, the peaks corresponding to (peak at $\left.2 \Theta=13^{\circ}\right)$ are lower, indicating the lower content of the $\alpha$-phase.
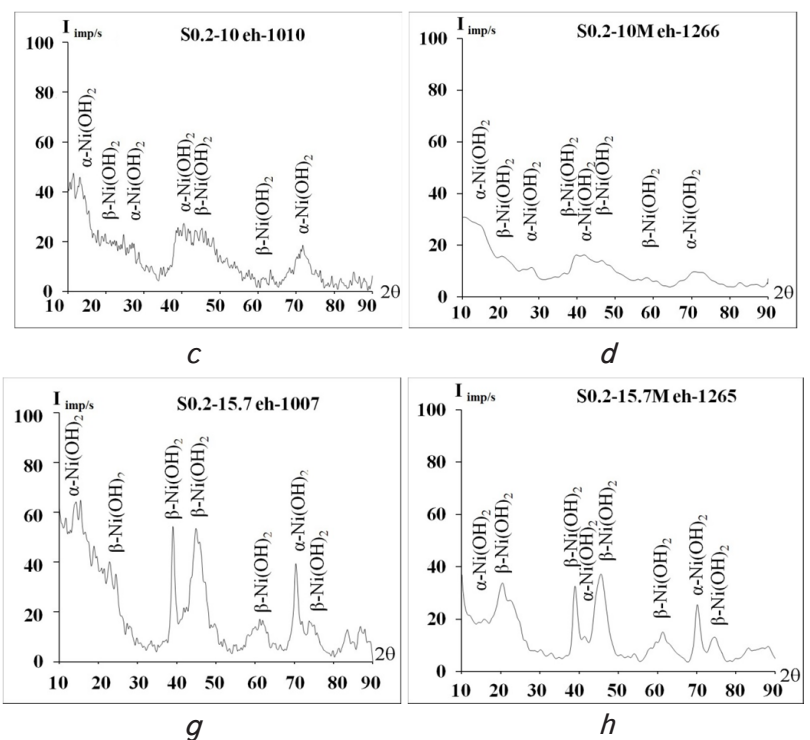

$f$-S0.2-12M; $g-\mathrm{S} 0.2-15.7 ; h-\mathrm{S} 0.2-15.7 \mathrm{M}$ 
5. 1. Influence of carbonate ions on electrochemical characteristics of samples

Results of cyclic voltammetry for the samples synthesized with the membrane (without carbonate) are shown in Fig. 2. Cyclic curves of the samples S0.2-8M and S0.2-10M show a pronounced first charge peak, with one charge and one discharge peak on the subsequent cycles. At the same time, the samples S0.2-12M and S0.2-15.7M show no pronounced first peak, and two charge peaks on the cycles $2-5$. Fluctuation of current density indicates the occurrence of side-reactions.

Fig. 3 shows the specific capacities of all synthesized samples.

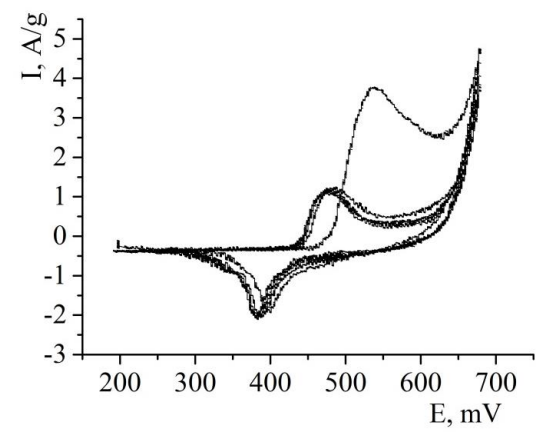

$a$

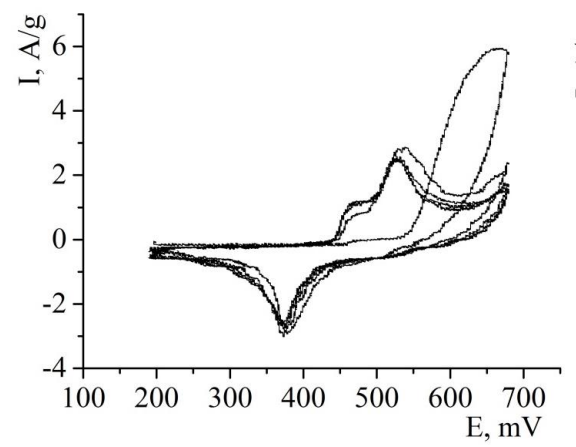

C

Fig. 2. Cyclic voltammograms of $\mathrm{Ni}(\mathrm{OH})_{2}$ samples: $a-\mathrm{S} 0.2-8 \mathrm{M}, b-\mathrm{S} 0.2-10 \mathrm{M} ; c$ $-\mathrm{S} 0.2-12 \mathrm{M} ; d-\mathrm{S} 0.2-15.7 \mathrm{M}$

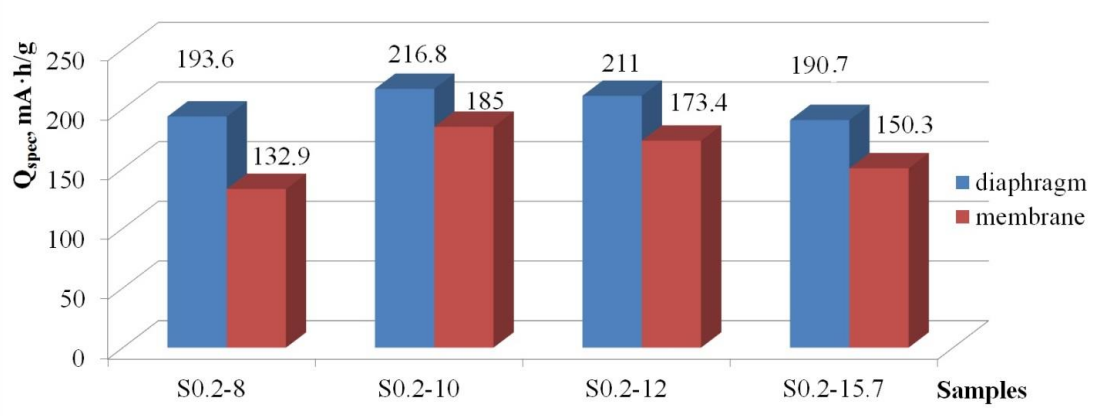

Fig. 3. Specific capacity of different nickel hydroxide samples, $m A \cdot h / g$

\section{Discussion of study results on the influence of carbonate ions on characteristics on nickel hydroxide samples}

Before synthesis, the concentration of carbonate ions in the anolyte was determined. The concentration of sodium carbonate was $2.8 \mathrm{~g} / \mathrm{l}$. Filtration flow was determined using a U-shaped water manometer. The pressure difference between the anodic and cathodic chambers was $10 \mathrm{~cm}$ of water $(98.7 \mathrm{~Pa})$. With pressure being lower in the cathodic chamber. Consequently, the filtering flow was directed from the anodic chamber to the cathodic chamber. Thus, it was confirmed that synthesis in the SDE with the membrane occurs in the presence of carbonate ions. The main mechanism of hydroxide formation - chemical precipitation upon the reaction of nickel cation with hydroxyls formed at the cathode. The carbonate ions leaked from the anolyte into the catholyte can take part in the formation of nickel hydroxide.

Influence on the crystal structure of nickel hydroxide samples. Results of XRD analysis (Fig. 1) have revealed that the samples synthesized in the presence of carbonate ions (when the diaphragm is used) are constituted by the layered $(\alpha+\beta)$ structure that contains both forms with the corresponding peaks appearing on XRD-patterns. During synthesis in the absence of carbonate (when the membrane is used), crystal structure changes. XRD-patterns of the samples $\mathrm{S} 0.2-8 \mathrm{M}$ and S0.2-10M show lower crystallinity in comparison to the samples S0.2-8 and S0.2-10, synthesized in the presence of carbonate. For the samples synthesized at higher current densities (samples S0.2-12M and S0.2-15.7M), rapid decrease in crystallinity was observed, along with the disappearance of peaks corresponding to the $\alpha$-form. This indicates that in the absence of carbonate ions, the $\alpha$-form is formed in lesser quantities. It is possible; that at higher current densities (12 and $15.7 \mathrm{~A} / \mathrm{dm}^{2}$ ), a bi-phase system is formed. It is possible; that carbonate ions intercalated into the primal particle become formation centers of metastable $\alpha$-form and stabilize it. Sulfate anions seem to also play this role, but their structure-forming and stabilizing capability appears to be lower than that of carbonates.

Influence on electrochemical characteristics of nickel hydroxide samples.

It can be observed that specific capacity of the samples synthesized with the diaphragm (with carbonate) and with the membrane (no carbonate); depends on synthesis current density and shows maximum at $12 \mathrm{~A} / \mathrm{dm}^{2}$. At the same time, it is worth noting, that for all synthesis current densities, the samples synthesized in the presence of carbonates (with the diaphragm) have higher capacities than those without carbonate (with membrane).
Cyclic voltammogram of the samples synthesized in the absence of carbonates (with use of membrane) (Fig. 2) showed the following. At a low current density $\left(8\right.$ and $\left.10 \mathrm{~A} / \mathrm{dm}^{2}\right)$, the electrochemical behavior of the samples doesn't have any characteristic differences. However, for the samples prepared at a current density of 12 and $15.7 \mathrm{~A} / \mathrm{dm}^{2}$ (S0.2-12M and $\mathrm{S} 0.2-15.7 \mathrm{M})$, no first charge peak is observed on cyclic voltammograms (which is characteristic of the $\beta$-form). It is 
worth highlighting; that later cycles showed two charge peaks that correspond to the $\beta$-form and $\alpha$-form. Thus, the absence of carbonate ions leads to the formation of the bi-phase system composed of $\beta-\mathrm{Ni}(\mathrm{OH})_{2}$ and $(\alpha+\beta)-\mathrm{Ni}(\mathrm{OH})_{2}$, which is in agreement with XRD results. Consequently, results of cyclic voltammetry for the samples synthesized with the diaphragm are similar to those of the monophase layered $(\alpha+\beta)$ structure of nickel hydroxide described in the literature [43]. So, cyclic voltammetry reveals the key role of carbonates in the formation of a unique monophase layered $(\alpha+\beta) \mathrm{Ni}(\mathrm{OH})_{2}$ structure.

Charge-discharge cycling in the accumulator regime revealed that the character of specific capacity dependency on synthesis current density is the same for synthesis with the diaphragm (in the presence of carbonate) and with the membrane (in the absence of carbonate). The dependency shows the extreme character, with the maximum capacity obtained for the samples synthesized at $10 \mathrm{~A} / \mathrm{dm}^{2}$ (S0.2-10 and S0.2-10M). However, regardless of synthesis current density, the samples synthesized in the absence of carbonates (with the membrane) show lower specific capacity than the samples synthesized in the presence of carbonates (with the diaphragm). Decrease of capacity in the series "S0.2-8M - S0.2-10M - S0.2-12M S $0.2-15.7 \mathrm{M}$ " is $31.4 \%, 14.7 \%, 17.8 \%$ and $21.2 \%$ respectively. This indicates lower electrochemical activity of the samples synthesized in the absence of carbonates.

It worth to note; that the study allows recommending the use of a diaphragm for industrial-scale synthesis in the SDE. It also recommended using technical-grade alkali, which is known to contain carbonate, as the anolyte to reduce costs. However, carbonate content and the presence of other anions should be controlled. The specific capacity of nickel hydroxide can also be improved by the additional introduction of sodium carbonate into the anolyte, however, this aspect requires additional studies.

\section{Conclusions}

1. Synthesis of nickel hydroxide in the slit-diaphragm electrolyzer was conducted with the use of the diaphragm and the cation-exchange membrane. The presence of the filtering anolyte flow (containing carbonate ions) into the cathodic chamber was experimentally confirmed for synthesis with the diaphragm. This confirms that the samples synthesized with the diaphragm are formed in the presence of carbonate ions, while the samples synthesized with the membrane - in the absence of carbonates.

2. By means of XRD analysis and cyclic voltammetry, the key role of carbonate anions in the formation of monophase layered $(\alpha+\beta)$ form has been revealed. The absence of carbonate results in a lower content of the $\alpha$-from, and at high current densities (12 and $\left.15.7 \mathrm{~A} / \mathrm{dm}^{2}\right)$ a bi-phase system, composed of a mixture of the $\beta$-from and $(\alpha+\beta)$-structure is formed.

3. Comparative analysis of electrochemical characteristics of $\mathrm{Ni}(\mathrm{OH})_{2}$, samples synthesized in the SDE in the presence (with the diaphragm) and absence (with the membrane) of carbonates has been conducted. It was discovered that the formation of the hydroxide in the SDE without carbonates leads to the reduction of specific capacity by $14.7-31.4 \%$. The highest specific capacity was obtained for the samples synthesized in the SDE at $i=10 \mathrm{~A} / \mathrm{dm}^{2}$ with the diaphragm (in the presence of carbonates) and with the membrane (in the absence of carbonates), and are 216.8 and $185 \mathrm{~mA} \cdot \mathrm{h} / \mathrm{g}$ respectively. To increase specific capacity, it is recommended to conduct a synthesis in the SDE with the use of the diaphragm and technical-grade alkali while controlling the content of carbonates and admixture of other anions. It is noted that the introduction of additional quantities of sodium carbonate into the anolyte can be promising.

\section{References}

1. Nickel hydroxides and related materials: a review of their structures, synthesis and properties / Hall D. S., Lockwood D. J., Bock C., MacDougall B. R. // Proceedings of the Royal Society A: Mathematical, Physical and Engineering Sciences. 2014. Vol. 471, Issue 2174. P. 20140792-20140792. doi: https://doi.org/10.1098/rspa.2014.0792

2. Vidotti M., Torresi R., Torresi S. I. C. de. Nickel hydroxide modified electrodes: a review study concerning its structural and electrochemical properties aiming the application in electrocatalysis, electrochromism and secondary batteries // Química Nova. 2010. Vol. 33, Issue 10. P. 2176-2186. doi: https://doi.org/10.1590/s0100-40422010001000030

3. Chen J. Nickel Hydroxide as an Active Material for the Positive Electrode in Rechargeable Alkaline Batteries // Journal of The Electrochemical Society. 1999. Vol. 146, Issue 10. P. 3606. doi: https://doi.org/10.1149/1.1392522

4. Cobalt-Free Nickel Rich Layered Oxide Cathodes for Lithium-Ion Batteries / Sun Y.-K., Lee D.-J., Lee Y. J., Chen Z., Myung S.-T. // ACS Applied Materials \& Interfaces. 2013. Vol. 5, Issue 21. P. 11434-11440. doi: https://doi.org/10.1021/am403684z

5. Asymmetric supercapacitors based on stabilized $\alpha-\mathrm{Ni}(\mathrm{OH}) 2$ and activated carbon / Lang J.-W., Kong L.-B., Liu M., Luo Y.-C., Kang L. // Journal of Solid State Electrochemistry. 2009. Vol. 14, Issue 8. P. 1533-1539. doi: https://doi.org/10.1007/s10008-009-0984-1

6. A facile approach to the preparation of loose-packed $\mathrm{Ni}(\mathrm{OH}) 2$ nanoflake materials for electrochemical capacitors / Lang J.-W., Kong L.-B., Wu W.-J., Liu M., Luo Y.-C., Kang L. // Journal of Solid State Electrochemistry. 2008. Vol. 13, Issue 2. P. 333-340. doi: https://doi.org/10.1007/s10008-008-0560-0

7. Electrochemical preparation of $\alpha-\mathrm{Ni}(\mathrm{OH}) 2$ ultrafine nanoparticles for high-performance supercapacitors / Aghazadeh M., Ghaemi M., Sabour B., Dalvand S. // Journal of Solid State Electrochemistry. 2014. Vol. 18, Issue 6. P. 1569-1584. doi: https://doi.org/ 10.1007/s10008-014-2381-7

8. Excellent supercapacitive performance of a reduced graphene oxide/ $\mathrm{Ni}(\mathrm{OH})_{2}$ composite synthesized by a facile hydrothermal route / Zheng C., Liu X., Chen Z., Wu Z., Fang D. // Journal of Central South University. 2014. Vol. 21, Issue 7. P. $2596-2603$. doi: https://doi.org/10.1007/s11771-014-2218-7

9. Hierarchical NiAl Layered Double Hydroxide/Multiwalled Carbon Nanotube/Nickel Foam Electrodes with Excellent Pseudocapacitive Properties / Wang B., Williams G. R., Chang Z., Jiang M., Liu J., Lei X., Sun X. // ACS Applied Materials \& Interfaces. 2014. Vol. 6, Issue 18. P. 16304-16311. doi: https://doi.org/10.1021/am504530e 
10. Kotok V., Kovalenko V. The properties investigation of the faradaic supercapacitor electrode formed on foamed nickel substrate with polyvinyl alcohol using // Eastern-European Journal of Enterprise Technologies. 2017. Vol. 4, Issue 12 (88). P. 31-37. doi: https:// doi.org/10.15587/1729-4061.2017.108839

11. Effect of deposition time on properties of electrochromic nickel hydroxide films prepared by cathodic template synthesis / Kotok V. A., Kovalenko V. L., Solovov V. A., Kovalenko P. V., Ananchenko B. A. // ARPN Journal of Engineering and Applied Sciences. 2018. Vol. 13, Issue 9. P. 3076-3086.

12. Kotok V., Kovalenko V. A study of the effect of tungstate ions on the electrochromic properties of Ni(OH $)_{2}$ films // Eastern-European Journal of Enterprise Technologies. 2018. Vol. 5, Issue 12 (95). P. 18-24. doi: https://doi.org/10.15587/1729-4061.2018.145223

13. Electrocatalytic oxidation of methanol at $\mathrm{Ni}-\mathrm{Al}$ layered double hydroxide film modified electrode in alkaline medium / Wang Y., Zhang D., Peng W., Liu L., Li M. // Electrochimica Acta. 2011. Vol. 56, Issue 16. P. 5754-5758. doi: https://doi.org/10.1016/ j.electacta.2011.04.049

14. Oscillatory electrocatalytic oxidation of methanol on an $\mathrm{Ni}(\mathrm{OH})_{2}$ film electrode / Huang W., Li Z. L., Peng Y. D., Chen S., Zheng J. F., Niu Z. J. // Journal of Solid State Electrochemistry. 2005. Vol. 9, Issue 5. P. 284-289. doi: https://doi.org/10.1007/ s10008-004-0599-5

15. Hierarchical Macro-Mesoporous $\mathrm{Ni}(\mathrm{OH})_{2}$ for Nonenzymatic Electrochemical Sensing of Glucose / Fan Y., Yang Z., Cao X., Liu P., Chen S., Cao Z. // Journal of the Electrochemical Society. 2014. Vol. 161, Issue 10. P. B201-B206. doi: https://doi.org/ $10.1149 / 2.0251410$ jes

16. Electrocatalysis and electroanalysis of nickel, its oxides, hydroxides and oxyhydroxides toward small molecules / Miao Y., Ouyang L., Zhou S., Xu L., Yang Z., Xiao M., Ouyang R. // Biosensors and Bioelectronics. 2014. Vol. 53. P. 428-439. doi: https://doi.org/ 10.1016/j.bios.2013.10.008

17. Ramesh T. N., Kamath P. V., Shivakumara C. Correlation of Structural Disorder with the Reversible Discharge Capacity of Nickel Hydroxide Electrode / Miao Y., Ouyang L., Zhou S., Xu L., Yang Z., Xiao M., Ouyang R. // Journal of The Electrochemical Society. 2005. Vol. 152, Issue 4. P. A806. doi: https://doi.org/10.1149/1.1865852

18. Zhao Y., Zhu Z., Zhuang Q.-K. The relationship of spherical nano-Ni(OH $)_{2}$ microstructure with its voltammetric behavior // Journal of Solid State Electrochemistry. 2005. Vol. 10, Issue 11. P. 914-919. doi: https://doi.org/10.1007/s10008-005-0035-5

19. Jayashree R. S., Kamath P. V., Subbanna G. N. The Effect of Crystallinity on the Reversible Discharge Capacity of Nickel Hydroxide // Journal of The Electrochemical Society. 2000. Vol. 147, Issue 6. P. 2029. doi: https://doi.org/10.1149/1.1393480

20. Jayashree R. S., Kamath P. V. Factors governing the electrochemical synthesis of $\alpha$-nickel (II) hydroxide // Journal of Applied Electrochemistry. 1999. Vol. 29, Issue 4. P. 449-454. doi: https://doi.org/10.1023/a:1003493711239

21. Ramesh T. N., Kamath P. V. Synthesis of nickel hydroxide: Effect of precipitation conditions on phase selectivity and structural disorder // Journal of Power Sources. 2006. Vol. 156, Issue 2. P. 655-661. doi: https://doi.org/10.1016/j.jpowsour.2005.05.050

22. Rajamathi M., Vishnu Kamath P., Seshadri R. Polymorphism in nickel hydroxide: role of interstratification // Journal of Materials Chemistry. 2000. Vol. 10, Issue 2. P. 503-506. doi: https://doi.org/10.1039/a905651c

23. Structural transformation and its effects on the electrochemical performances of a layered double hydroxide / Hu M., Yang Z., Lei L., Sun Y. // Journal of Power Sources. 2011. Vol. 196, Issue 3. P. 1569-1577. doi: https://doi.org/10.1016/j.jpowsour.2010.08.041

24. Effect of Additives in the Stabilization of the $\alpha$ Phase of $\mathrm{Ni}(\mathrm{OH})_{2}$ Electrodes / Cordoba de Torresi S. I., Provazi K., Malta M., Torresib R. M. // Journal of The Electrochemical Society. 2001. Vol. 148, Issue 10. P. A1179-A1184. doi: https://doi.org/ $10.1149 / 1.1403731$

25. Structural and Electrochemical Performance of Additives-doped $\alpha$-Ni(OH $)_{2} /$ Zhang Z., Zhu Y., Bao J., Zhou Z., Lin X., Zheng H. // Journal of Wuhan University of Technology-Mater. Sci. Ed. 2012. Vol. 27, Issue 3. P. 538-541. doi: https://doi.org/10.1007/s11595012-0500-9

26. Sugimoto A., Ishida S., Kenzo H. Preparation and Characterization of Ni/Al-Layered Double Hydroxide // Journal of The Electrochemical Society. 1999. Vol. 146, Issue 4. P. 1251-1255. doi: https://doi.org/10.1149/1.1391754

27. A study on the structure and electrochemical characteristics of a Ni/Al double hydroxide / Zhen F. Z., Quan J. W., Min Y. L., Peng Z., Jun J. L. // Metals and Materials International. 2004. Vol. 10, Issue 5. P. 485-488. doi: https://doi.org/10.1007/bf03027353

28. Physical and electrochemical characteristics of aluminium-substituted nickel hydroxide / Liu B., Wang X. Y., Yuan H. T., Zhang Y. S., Song D. Y., Zhou Z. X. // Journal of Applied Electrochemistry. 1999. Vol. 29, Issue 7. P. 853-858. doi: https:// doi.org/10.1023/a:1003537900947

29. Caravaggio G. A., Detellier C., Wronski Z. Synthesis, stability and electrochemical properties of NiAl and NiV layered double hydroxides // Journal of Materials Chemistry. 2001. Vol. 11, Issue 3. P. 912-921. doi: https://doi.org/10.1039/b004542j

30. Effect of interlayer anions on the electrochemical performance of Al-substituted $\alpha$-type nickel hydroxide electrodes / Li Y. W., Yao J. H., Liu C. J., Zhao W. M., Deng W. X., Zhong S. K. // International Journal of Hydrogen Energy. 2010. Vol. 35, Issue 6. P. 2539-2545. doi: https://doi.org/10.1016/j.ijhydene.2010.01.015

31. Al-substituted $\alpha$-nickel hydroxide prepared by homogeneous precipitation method with urea / Zhao Y. L., Wang J. M., Chen H., Pan T., Zhang J. Q., Cao C. N. // International Journal of Hydrogen Energy. 2004. Vol. 29, Issue 8. P. 889-896. doi: https:// doi.org/10.1016/j.ijhydene.2003.10.006

32. The effect of the interlayer anions on the electrochemical performance of layered double hydroxide electrode materials / Lei L., Hu M., Gao X., Sun Y. // Electrochimica Acta. 2008. Vol. 54, Issue 2. P. 671-676. doi: https://doi.org/10.1016/j.electacta.2008.07.004 
33. Correlation among Structure, Microstructure, and Electrochemical Properties of NiAl-CO3 Layered Double Hydroxide Thin Films / Faour A., Mousty C., Prevot V., Devouard B., De Roy A., Bordet P. et. al. // The Journal of Physical Chemistry C. 2012. Vol. 116, Issue 29. P. 15646-15659. doi: https://doi.org/10.1021/jp300780w

34. Kotok V., Kovalenko V., Vlasov S. Investigation of $\mathrm{Ni}-\mathrm{Al}$ hydroxide with silver addition as an active substance of alkaline batteries // Eastern-European Journal of Enterprise Technologies. 2018. Vol. 3, Issue 6 (93). P. 6-11. doi: https://doi.org/ $10.15587 / 1729-4061.2018 .133465$

35. Kovalenko V., Kotok V. Study of the influence of the template concentration under homogeneous precepitation on the properties of $\mathrm{Ni}(\mathrm{OH})_{2}$ for supercapacitors // Eastern-European Journal of Enterprise Technologies. 2017. Vol. 4, Issue 6 (88). P. 17-22. doi: https://doi.org/10.15587/1729-4061.2017.106813

36. Kovalenko V., Kotok V. Obtaining of Ni-Al layered double hydroxide by slit diaphragm electrolyzer // Eastern-European Journal of Enterprise Technologies. 2017. Vol. 2, Issue 6 (86). P. 11-17. doi: https://doi.org/10.15587/1729-4061.2017.95699

37. Kovalenko V., Kotok V. Definition of effectiveness of $\beta-\mathrm{Ni}(\mathrm{OH})_{2}$ application in the alkaline secondary cells and hybrid supercapacitors // Eastern-European Journal of Enterprise Technologies. 2017. Vol. 5, Issue 6 (89). P. 17-22. doi: https://doi.org/ 10.15587/1729-4061.2017.110390

38. A facile approach to synthesis coral-like nanoporous $\beta-\mathrm{Ni}(\mathrm{OH})_{2}$ and its supercapacitor application / Li J., Luo F., Tian X., Lei Y., Yuan H., Xiao D. // Journal of Power Sources. 2013. Vol. 243. P. 721-727. doi: https://doi.org/10.1016/j.jpowsour.2013.05.172

39. Kovalenko V., Kotok V. Influence of ultrasound and template on the properties of nickel hydroxide as an active substance of supercapacitors // Eastern-European Journal of Enterprise Technologies. 2018. Vol. 3, Issue 12 (93). P. 32-39. doi: https:// doi.org/10.15587/1729-4061.2018.133548

40. Nickel hydroxide obtained by high-temperature two-step synthesis as an effective material for supercapacitor applications / Kovalenko V. L., Kotok V. A., Sykchin A. A., Mudryi I. A., Ananchenko B. A., Burkov A. A. et. al. // Journal of Solid State Electrochemistry. 2016. Vol. 21, Issue 3. P. 683-691. doi: https://doi.org/10.1007/s10008-016-3405-2

41. Synthesis and electrochemical performance of mixed phase $\alpha / \beta$ nickel hydroxide by codoping with $\mathrm{Ca}^{2+}$ and $\mathrm{PO}_{4}^{3-} / \mathrm{Miao} \mathrm{C}$., Zhu Y., Zhao T., Jian X., Li W. // Ionics. 2015. Vol. 21, Issue 12. P. 3201-3208. doi: https://doi.org/10.1007/s11581-015-1507-y

42. Synthesis and electrochemical performance of mixed phase $\alpha / \beta$ nickel hydroxide / Li Y., Yao J., Zhu Y., Zou Z., Wang H. // Journal of Power Sources. 2012. Vol. 203. P. 177-183. doi: https://doi.org/10.1016/j.jpowsour.2011.11.081

43. Kovalenko V., Kotok V. Comparative investigation of electrochemically synthesized $(\alpha+\beta)$ layered nickel hydroxide with mixture of $\alpha-\mathrm{Ni}(\mathrm{OH})_{2}$ and $\beta-\mathrm{Ni}(\mathrm{OH})_{2} / /$ Eastern-European Journal of Enterprise Technologies. 2018. Vol. 2, Issue 6 (92). P. 16-22. doi: https://doi.org/10.15587/1729-4061.2018.125886

44. Kotok V., Kovalenko V., Malyshev V. Comparison of oxygen evolution parameters on different types of nickel hydroxide // Eastern-European Journal of Enterprise Technologies. 2017. Vol. 5, Issue 12 (89). P. 12-19. doi: https://doi.org/10.15587/17294061.2017.109770

45. Kotok V., Kovalenko V. Definition of the aging process parameters for nickel hydroxide in the alkaline medium // Eastern-European Journal of Enterprise Technologies. 2018. Vol. 2, Issue 12 (92). P. 54-60. doi: https://doi.org/10.15587/1729-4061.2018.127764

46. Antifriction and Construction Materials Based on Modified Phenol-Formaldehyde Resins Reinforced with Mineral and Synthetic Fibrous Fillers / Burmistr M. V., Boiko V. S., Lipko E. O., Gerasimenko K. O., Gomza Y. P., Vesnin R. L. et. al. // Mechanics of Composite Materials. 2014. Vol. 50, Issue 2. P. 213-222. doi: https://doi.org/10.1007/s11029-014-9408-0

47. Research of the mechanism of formation and properties of tripolyphosphate coating on the steel basis / Vlasova E., Kovalenko V., Kotok V., Vlasov S. // Eastern-European Journal of Enterprise Technologies. 2016. Vol. 5, Issue 5 (83). P. 33-39. doi: https://doi.org/ 10.15587/1729-4061.2016.79559

48. Deabate S., Fourgeot F., Henn F. Structural and electrochemical characterization of nickel hydroxide obtained by the new synthesis route of electrodialysis. a comparison with spherical $\beta-\mathrm{Ni}(\mathrm{OH})_{2} / /$ Ionics. 1999. Vol. 5, Issue 5-6. P. 371-384. doi: https://doi.org/ $10.1007 / \mathrm{bf} 02376001$

49. Kovalenko V., Kotok V., Kovalenko I. Activation of the nickel foam as a current collector for application in supercapacitors // Eastern-European Journal of Enterprise Technologies. 2018. Vol. 3, Issue 12 (93). P. 56-62. doi: https://doi.org/10.15587/17294061.2018.133472

50. Kotok V., Kovalenko V. Optimization of nickel hydroxide electrode of the hybrid supercapacitor // Eastern-European Journal of Enterprise Technologies. 2017. Vol. 1, Issue 6 (85). P. 4-9. doi: https://doi.org/10.15587/1729-4061.2017.90810 